\title{
The Influence of Earnings Response Coefficient (ERC) and Dividend Payout Ratio (DPR) on Stock Price
}

Regita Noer Aini, Jajang Badruzaman", Iwan Hermansyah

Accounting Study Program, Faculty of Economics and Business, Siliwangi University, Jl Siliwangi No.24, Kahuripan, Kec Tawang, Tasikmalaya, Jawa Barat 46115, Indonesia

DOI: $10.36348 /$ sjef.2020.v04i03.001

| Received: 20.01.2020 | Accepted: 27.01.2020 | Published: 08.03.2020

*Corresponding author: Jajang Badruzaman

\section{Abstract}

This study aims to determine (1) Earnings Response Coefficient, Dividend Payout Ratio, and Stock Price, (2) the effect of Dividend Payout Ratio on Earnings Response Coefficient, and (3) the effect of Earnings Response Coefficient and Dividend Payout Ratio partially and simultaneously on Stock Price in technology sector companies listed in the Nikkei 225 Index. Samples from this study are 57 technology sector companies listed in the Nikkei 225 Index which were selected using the technique sampling saturated (census). The analysis technique used is path analysis. The results showed that: (1) Earnings Response Coefficient, Dividend Payout Ratio, and Stock Price show varying results for each company, (2) Dividend Payout Ratio has a negative effect on Earnings Response Coefficient, and (3) Earnings Response Coefficient and Dividend Payout Ratio partially and simultaneously have a positive effect on Stock Price in technology sector companies listed in the Nikkei 225 Index.

Keywords: Earnings Response Coefficient, Dividend Payout Ratio, and Stock Price.

Copyright @ 2020: This is an open-access article distributed under the terms of the Creative Commons Attribution license which permits unrestricted use, distribution, and reproduction in any medium for non-commercial use (NonCommercial, or CC-BY-NC) provided the original author and source are credited.

\section{INTRODUCTION}

Earnings information is part of financial statements that gets a lot of attention. Lev and Zarowin [1] in Murwaningsari [2] use earnings response coefficient, hereinafter abbreviated as ERC, as an alternative to measure the value relevance of earnings information. Scott [3] argues that ERC is a measure of the amount of abnormal returns of a stock in response to an abnormal earnings component (unexpected earnings) reported by the company that issued the stock.

Investors respond to earnings information, one of them is payment of dividends. According to Sudana [4] the ratio of dividend payout ratio, hereinafter abbreviated as DPR, is the percentage of profit after tax distributed as dividends to shareholders. Kallapur [5] in Wijayanti and Supatmi [6] examines dividend payout ratio as an explanation for the ERC.

According to Tan Kwang En [7], one of the ideas from Ball and Brown is the fact that securities prices respond to the content of information that is usually contained in an event that will cause a market response and have an impact on changes in stock prices. This happened to one of the companies listed in the Nikkei 225 Index, Sony Corp. where stock prices changes related to information about company profits. According to Samsul [8] stock price is the price formed in the market whose amount is influenced by the law of demand and supply.

ERC shows the quality of earnings reported by the company. The higher ERC reflects the stronger market response to the earnings information. Because of the strong response it is expected that these profits will attract investors to invest in the company. The higher market demand can cause the higher stock price of the company.

According to Pranata et al., [9] in Nugraha and Sudaryanto [10], the higher DPR indicates the level of profit sharing is also high, this will increase investors' interest to buy the company's stocks and have an impact on increasing stock prices. But according to Brigham and Houston [11] in Ningrum [12], the higher DPR means the less profit retained, consequently inhibiting the growth rate in income and stock prices.

Based on the description above, the author assumes that the research on the effect of DPR on ERC is very important to know the market response to earnings information in this case is dividends. In 
addition, the value of ERC and DPR can have an impact on stock price too.

The problems that will be formulated in this study is how's the influence of Earnings Response Coefficient (ERC) and Dividend Payout Ratio (DPR) partially and simultaneously on Stock Price on the Technology Sector Companies listed in the Nikkei 225 Index 2018.

\section{LITERATURE STUDY \\ Earnings Response Coefficient}

According to Cho and Jung [13] in Murwaningsari [2], the earnings response coefficient is defined as the effect of every dollar of unexpected earnings on stock returns, and is measured by the slope coefficient of the regression of abnormal returns stock and unexpected earnings. Scott [3] argues that ERC is a measure of the amount of abnormal returns of a stock in response to an earnings component abnormal (unexpected earnings) reported by the company that issued the stock. ERC consists of two indicators, they are:

\section{Cumulative Abnormal Return (CAR)}

According to Jogiyanto [14] cumulative abnormal return (CAR) is the sum of abnormal returns the previous day in the event period. Abnormal return is the difference between actual returns with normal returns (expected return).

\section{Unexpected Earning (UE)}

According to Gunawan and Prasetya [15], unexpected earnings (UE) is the difference between profits announced by companies with expected earnings. The existence of unexpected earnings will affect the stock price and return. If the announced profit is higher than the expected profit, UE is positive. Companies with positive UE are expected to give a positive response to stock returns, so UE's influence on stock returns is proportional.

Scott [16] in Delvira and Nelvirita [17] suggest several factors that influence ERC, they are:

1. Profit persistence. The more permanent changes in earnings can cause the higher ERC, this condition indicates that the company's profits increase continuously.

2. Capital structure (leverage). Companies with high leverage mean having a debt that is higher than capital. Thus, if there is an increase in profits, the beneficiaries are debtholders non-investor.

3. Systematic risk, is a risk associated with changes that occur in the market that affect the variability of returns investment so ERC becomes low.

4. The opportunity to grow, this factor shows the company's opportunity to increase profits in the future so that causes ERC to become high.

5. Company size. The larger size of the company mean that company has more information so investors will use the size of company as one of the factors that can be used in making investment decisions.

\section{Dividend Payout Ratio (DPR)}

Sudana [4] suggests that dividends are payments made by companies to shareholders, both in the form of cash and stocks. Kieso et al., [18] which was translated by Emil Salim stated that dividends consisted of several types including cash dividends, property dividends, liquidity dividends, and stock dividends. Cash dividends are the most common method for profit sharing. Property dividends paid in the form of company assets. Liquidation dividend is a dividend that is not based on retained earnings, which implies that this dividend is a return on shareholder investment and not from profit. Share dividends represent issuance by a company of its own shares to shareholders which are calculated in proportion to the number of shares held by each shareholder.

Management has two alternative treatments for the company's profits, which are shared with the company's shareholders in the form of dividends or reinvested in the company as retained earnings. Dividend policy relates to the determination of the amount of dividend payout ratio, that is the percentage of profit after tax that is distributed as dividends to shareholders [4]. Dividend payout ratio is calculated by formula:

$$
\text { Dividend Payout Ratio }=\frac{\text { Dividend Per Share }}{\text { Earning Per Share }}
$$

Based on the formula above, dividend payout ratio is a ratio between dividend per share (DPS) and earnings per share (EPS). Dividend per share is measured by a comparison between the amount of dividends paid and the number of stocks outstanding. While earnings per share is net income divided by the number of stocks outstanding.

\section{Stock Prices}

According to Fakhruddin [19] stocks are proof of equity participation in a company, or is proof of ownership of a company, which is then classified into several types as follows:

- From the way of the rights are transferred, it consists of bearer stocks and registered stocks.

- In terms of claim rights, it consists of common stocks and preferred stocks.

- From the trade performance, it consists of bluechip stocks, income stocks, growth stocks (wellknown), speculative stocks, and counter cyclical stocks.

Samsul [8] suggests that stock prices are prices formed in the market whose the amount is influenced by the law of demand and supply. Whereas Widoatmojo [20] classifies stock prices into several types, they are nominal price, initial price, market price, opening price, 
closing price, highest price, lowest price, and average price. The nominal price is the price stated in the stock certificate whose value is determined by the issuer to assess each stock issued. The initial price is the price at the first time the stocks are listed on the market. The market price is the selling price from one investor to another for the amount of the rupiah agreed upon by the seller and the buyer at the time of the transaction. The opening price is the price requested by the seller or buyer when the trading hours are opened. The closing price is the price requested by the seller or buyer at the end of the trading day. The highest price is the highest price that occurs on the trading day. The lowest price is the lowest price that occurs on the trading day. The average price is an average of all prices that occur on the trading day.

According to Setiawan and Kusrini [21] there are several factors that influence stock prices:

1. Return on equity (ROE) reflects the company's ability to generate profits for shareholders.

2. Price earnings ratio (PER), is the valuation of shares with a profit approach, meaning the expected return on the estimated earnings per share in the future so it can be known how long the stock investment will return.

3. Return on investment (ROI), measures the level of profit generated from total investment.

4. Earning per share (EPS), is a measure of a company's ability to generate profits per share for its owner.

5. Leverage, shows the proportion of debt usage to finance a company's investment, meaning that interest payments and loan capital to creditors must be done first before distributing profits to shareholders.

6. The exchange rate of the US Dollar against the Rupiah. If the dollar exchange rate increases, investors tend to sell their stocks or save their money first, consequently the stock price tends to fall.

\section{RESEARCH METHODS}

The method used by the author in this study is descriptive statistics with a census approach. The type of data used in this study is secondary data, that is, from the technology sector companies listed in the Nikkei 225 Index with a population of 57 companies in 2018.

\section{Measurement of Variables}

In this study author used three variables, which consist of:

1. Independent variables, which consist of:

\section{Earnings Response Coefficient $\left(\mathrm{X}_{1}\right)$}

Earnings Response Coefficient measured by the following steps:
Cumulative Abnormal Return (CAR)

$$
\mathrm{CAR}_{\mathrm{i}(-5,+5)}=\sum_{\mathrm{t}=-5}^{\mathrm{t}=+5} \mathrm{AR}_{\mathrm{it}}
$$

Description :

$\mathrm{CAR}_{\mathrm{i}(-5,+5)}=$ Cumulative abnormal return of i's company during the observation period ( 5 days before and after the publication date of the financial statement)

$\mathrm{AR}_{\mathrm{it}}=$ Abnormal return of i's company on $\mathrm{t}$ day

Abnormal return is calculated using the market adjusted model.

$$
\mathrm{AR}_{\mathrm{it}}=\mathrm{R}_{\mathrm{it}}-\mathrm{R}_{\mathrm{mt}}
$$

Description:

$\mathrm{AR}_{\mathrm{it}}=$ Abnormal return of $\mathrm{i}$ 's company on $\mathrm{t}$ event

$\mathrm{R}_{\mathrm{it}}=$ Return of i's company on $\mathrm{t}$ event

$\mathrm{R}_{\mathrm{mt}}=$ Market Return on t event

Return of company is measured by:

Description:

$$
\mathrm{R}_{\mathrm{it}}=\frac{\mathrm{P}_{\mathrm{t}}-\mathrm{P}_{\mathrm{t}-1}}{\mathrm{P}_{\mathrm{t}-1}}
$$

$\mathrm{R}_{\mathrm{it}}=$ Return of $\mathrm{i}$ 's company on $\mathrm{t}$ day

$\mathrm{P}_{\mathrm{t}}=$ Closing price on $\mathrm{t}$ day

$\mathrm{P}_{\mathrm{t}-1}=$ Closing price on $\mathrm{t}-1$ day

Maket return is measured by:

$$
\mathrm{R}_{\mathrm{mt}}=\frac{\mathrm{IHSG}_{\mathrm{t}}-\mathrm{IHSG}_{\mathrm{t}-1}}{\mathrm{IHSG}_{\mathrm{t}-1}}
$$

Description:

$\mathrm{R}_{\mathrm{mt}}=$ Market return on $\mathrm{t}$ day

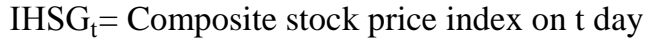

$\mathrm{IHSG}_{\mathrm{t}-1}=$ Composite stock price index on $\mathrm{t}-1$ day

Market return in this study use composite stock price indeks of Nikkei 225 which is the technology sector companies is included in it.

Unexpected Earnings (UE)

$$
\mathrm{UE}_{\mathrm{it}}=\frac{\mathrm{EPS}_{\mathrm{it}}-\mathrm{EPS}_{\mathrm{it}-1}}{\mathrm{P}_{\mathrm{it}-1}}
$$

Description:

$\mathrm{UE}_{\mathrm{it}}=$ Unexpected earnings of $\mathrm{i}$ 's company on t event

$\mathrm{EPS}_{\mathrm{it}}=$ Earnings per share of i's company on $\mathrm{t}$ event

EPS $_{\text {it- } 1}=$ Earnings per share of i's company on t-1 event

$\mathrm{P}_{\mathrm{it}-1}=$ Stock price of i's company on $\mathrm{t}-1$ event 
Earnings Response Coefficient (ERC)

$\mathrm{ERC}$ is the coefficient that obtained from the following equation:

$$
\mathrm{CAR}_{\mathrm{it}}=\beta_{0}+\beta_{1} \mathrm{UE}_{\mathrm{it}}+\varepsilon_{\mathrm{it}}
$$

Description:

$$
\begin{aligned}
& \text { CAR }_{\text {it }}=\text { CAR of } i \text { 's company on t event } \\
& \text { UE }_{\text {it }}=\text { UE of } i \text { 's company on t event } \\
& \beta_{0}=\text { Constant } \\
& \beta_{1}=\text { Coefficient, that is ERC } \\
& \varepsilon_{\text {it }}=\text { Error component in the model of i's } \\
& \text { company on t event }
\end{aligned}
$$

a. Dividend Payout Ratio $\left(\mathrm{X}_{2}\right)$.

Dividend payout ratio is measured by:

$$
\text { Dividend Payout Ratio }=\frac{\text { Dividend Per Share }}{\text { Earning Per Share }}
$$

Dependent variable is stock price which is measured by the closing price on the publication date of financial statement.

\section{RESULT AND DISCUSSION}

Based on the results that have been conducted, the result showed that dividend payout ratio has a negative effect on earnings response coefficient, and earnings response coefficient and dividend payout ratio partially and simultaneously have a positive effect on stock price in technology sector companies listed in the nikkei 225 Index.

\section{The Influence of Dividend Payout Ratio (DPR) on Earnings Response Coefficient (ERC)}

To determine the influence of DPR $\left(\mathrm{X}_{2}\right)$ on ERC $\left(\mathrm{X}_{1}\right)$, it can be seen from the beta coefficient value obtained from the calculation of SPSS version 23 which is equal to -0.160 , meaning that DPR has a negative effect on ERC. This shows that when DPR increases, ERC will decrease by $16 \%$.

The coefficient of determination that shows the magnitude of the influence of DPR on ERC is equal to $(-0.160)^{2}=0.026$ or $2.6 \%$. This means that ERC is influenced by DPR by $2.6 \%$. The remaining $1-0.026=$ 0.974 or $97.4 \%$ is the influence of other factors not examined on ERC which are allegedly among others, earnings persistence, capital structure, systematic risk, growth opportunities, and company size.

This is not in line with the research conducted by Husiano and Suratno [22], and Yuniarta [23] which shows that DPR has a positive effect on ERC. According to the author, the results of this study are different from previous studies because ERC's indicator CAR uses a different observation period, 7 days of stock trading in Yuniarta [23] and 3 days of stock trading in Husiano and Suratno [22], while the author's observation period is 11 days of stock trading.
The Influence of Earnings Response Coefficient (ERC) Partially on Stock Price

To determine the influence of $\operatorname{ERC}\left(\mathrm{X}_{1}\right)$ on stock price $(\mathrm{Y})$ it can be seen from the beta coefficient value obtained from the calculation of SPSS version 23 which is equal to 0.142 , meaning that ERC partially has a positive effect on stock price. This shows that when ERC increases, the share price will increase by $14.2 \%$.

The coefficient of determination that shows the magnitude of the effect of ERC on stock price is equal to $(0.142)^{2}=0.020$ or $2 \%$. This means that the stock price is affected by ERC of $2 \%$. The remaining 1 $0.020=0.980$ or $98 \%$ is the influence of other factors that are not examined against the stock price which is thought to be among others, namely ROE, PER, ROI, EPS, leverage, and exchange rates.

This is in line with the research by Tan Kwang En [7] and Paramita and Hidayanti [24] which states that ERC has an effect on stock price even though there is no significant influence between ERC and the company's stock price in both studies.

\section{The Influence of Dividend Payout Ratio (DPR) Partially on Stock Price}

To determine the influence of DPR $\left(\mathrm{X}_{2}\right)$ on stock price $(\mathrm{Y})$ it can be seen from the beta coefficient value obtained from the calculation of SPSS version 23 which is equal to 0.151 meaning that DPR has a positive effect on stock price. This shows that when DPR experiences an increase, the share price will also increase by $15.1 \%$.

The coefficient of determination that shows the magnitude of DPR's direct influence on stock price is equal to $(0.151)^{2}=0.023$ or $2.3 \%$. This means that the stock price is influenced by DPR of $2.3 \%$. The remaining $1-0.023=0.977$ or $97.7 \%$ is the effect of other factors not examined on stock price which are allegedly among others, namely ROE, PER, ROI, EPS, leverage, and exchange rates.

In addition to the direct effect of 0.023 , DPR also has an indirect influence on stock price through ERC, which is equal to -0.007 so that the total influence of DPR on the share price is 0.016. This is in line with the research conducted by Sihombing [25], Nugraha and Sudaryanto [10], and Wijaya and Suarjaya [26] which show that DPR has a positive effect on stock price.

\section{The Influence of Earnings Response Coefficient (ERC) and Dividend Payout Ratio (DPR) Simultaneously on Stock Price}

To determine the influence of $\operatorname{ERC}\left(\mathrm{X}_{1}\right)$ and DPR $\left(\mathrm{X}_{2}\right)$ on stock price $(\mathrm{Y})$, then testing is done using SPSS version 23 . The results of data processing indicate that the value of the correlation coefficient $(\mathrm{R})$ between variables $\mathrm{X}_{1}$ and $\mathrm{X}_{2}$ to $\mathrm{Y}$ is 0.190 which indicates a very 
low level of relationship because the value is between 0 , 00 - 0,1999. This means that the magnitude of the relationship or correlation between ERC and DPR on stock price by $19 \%$.

The coefficient of determination ( $\mathrm{R}$ square) which shows the magnitude of the influence of ERC and DPR on stock price is equal to 0.036 , so the magnitude of the influence of ERC and DPR simultaneously on the stock price is $3.6 \%$. This means that ERC and DPR simultaneously have a positive effect on stock price, meaning that if ERC and DPR increase, then the share price will also increase by $3.6 \%$. The remaining $1-0.036=0.964$ or $96.4 \%$ is the effect of other factors not examined on stock price other than ERC and DPR, which are alleged to include ROE, PER, ROI, EPS, leverage, and exchange rates.

The influence of ERC and DPR on stock price both directly or indirectly is presented below:

Table-1: Results of Calculation of Direct and Indirect Effects between Research Variables

\begin{tabular}{|c|c|c|}
\hline No. & Direct Effects & Indirect Effects \\
\hline \multirow[t]{2}{*}{1.} & $\begin{array}{l}\mathrm{Y} \leftarrow \mathrm{X}_{1} \rightarrow \mathrm{Y}=\left(\rho_{\mathrm{YX}_{1}}\right)^{2} \\
\mathrm{Y} \leftarrow \mathrm{X}_{1} \rightarrow \mathrm{Y}=(0,142)^{2}\end{array}$ & \\
\hline & Total effect of $X_{1}$ & \\
\hline \multirow[t]{5}{*}{2.} & $\begin{array}{l}\mathrm{Y} \leftarrow \mathrm{X}_{2} \rightarrow \mathrm{Y}=\left(\rho_{\mathrm{YX}_{2}}\right)^{2} \\
\mathrm{Y} \leftarrow \mathrm{X}_{1} \rightarrow \mathrm{Y}=(0,151)^{2}\end{array}$ & \\
\hline & & $\begin{array}{l}\text { Melalui } \mathrm{X}_{1} \text {, } \\
\qquad \mathrm{Y} \leftarrow \mathrm{X}_{2} \Omega \mathrm{X}_{1} \rightarrow \mathrm{Y} \\
=\left(\rho_{\mathrm{YX}_{2}} \cdot \rho_{\mathrm{X}_{1} \mathrm{X}_{2}} \cdot \rho_{\mathrm{YX}_{1}}\right)+\left(\rho_{\mathrm{YX}_{2}} \cdot \rho_{\mathrm{X}_{1} \mathrm{X}_{2}} \cdot \rho_{\mathrm{YX}_{1}}\right) \\
=(0,151)(-0,160)(0,142)+ \\
(0,151)(-0,160)(0,142)\end{array}$ \\
\hline & Total effect of $X_{2}$ & $0,023+(-0,007)$ \\
\hline & Total effect of $X_{1}$ and $X_{2}$ & $0,020+0,016$ \\
\hline & Residual effect & $1-0,036$ \\
\hline
\end{tabular}

The calculation results show that the direct effect of ERC on stock price is $2 \%$. House influence directly to the stock price of $2.3 \%$, while the indirect effect through ERC is $-0.7 \%$ so that the DPR has a total influence on the stock price of $1.6 \%$. The total influence of ERC and DPR on the share price is $3.6 \%$.
The calculation results in Table-1 also show that there are other factors that influence stock price in addition to ERC and DPR which have an influence of 96.4\%. Other factors include ROE, EPS, ROI, PER, leverage, and exchange rate can be used by investors to make investment decisions.

\section{ATTACHMENT}

\section{Recapitulation of Research Result}

\begin{tabular}{|l|l|l|l|l|}
\hline Code & Company's Name & ERC & DPR & Stock Price \\
\hline 4151 & Kyowa Hakko Kirin Co., Ltd. & 87,68 & 35,25 & $2.111,00$ \\
\hline 4502 & Takeda Pharmaceutical Co., Ltd. & $-3,45$ & 7,58 & $4.798,00$ \\
\hline 4503 & Astellas Pharma Inc. & $-73,00$ & 44,43 & $1.544,50$ \\
\hline 4506 & Sumitomo Dainippon Pharma Co., Ltd. & 2,25 & 20,81 & $1.837,00$ \\
\hline 4507 & Shionogi \& Co., Ltd. & 15,50 & 24,30 & $5.477,00$ \\
\hline 4519 & Chugai Pharmaceutical Co., Ltd. & $-6,11$ & 50,95 & $6.420,00$ \\
\hline 4523 & Eisai Co., Ltd. & 3,32 & 82,89 & $7.320,00$ \\
\hline 4568 & Daiichi Sankyo Co., Ltd. & 6,72 & 76,84 & $3.750,00$ \\
\hline 4578 & Otsuka Holdings Co., Ltd. & 13,15 & 66,11 & $4.469,00$ \\
\hline 3105 & Nisshinbo Holdings Inc. & 8,83 & 18,70 & 976,00 \\
\hline 6479 & Minebea Mitsumi Inc. & 30,86 & 18,87 & $2.237,00$ \\
\hline 6501 & Hitachi Ltd. & 33,80 & 19,97 & $4.008,00$ \\
\hline 6503 & Mitsubishi Electric Corp. & 80,44 & 31,57 & $1.680,50$ \\
\hline 6504 & Fuji Electric Co., Ltd. & $-40,15$ & 26,48 & $3.655,00$ \\
\hline 6506 & Yaskawa Electric Corp. & 0,25 & 24,46 & $4.740,00$ \\
\hline 6645 & Omron Corp. & 74,24 & 25,60 & $5.980,00$ \\
\hline 6674 & GS Yuasa Corp. & $-26,52$ & 38,62 & $2.945,00$ \\
\hline 6701 & NEC Corp. & 11,67 & 33,99 & $3.005,00$ \\
\hline 6702 & Fujitsu Ltd. & 23,86 & 13,33 & $6.659,00$ \\
\hline
\end{tabular}




\begin{tabular}{|l|l|l|l|l|}
\hline 6703 & Oki Electric Industry Co., Ltd. & 4,01 & 73,77 & $1.502,00$ \\
\hline 6724 & Seiko Epson Corp. & 8,58 & 52,21 & $2.055,00$ \\
\hline 6752 & Panasonic Corp. & 28,91 & 29,66 & $1.562,00$ \\
\hline 6758 & Sony Corp. & 10,59 & 7,24 & $5.400,00$ \\
\hline 6762 & TDK Corp. & $-10,65$ & 25,92 & $9.450,00$ \\
\hline 6770 & Alps Alpine Co., Ltd. & 58,84 & 15,30 & $2.638,00$ \\
\hline 6841 & Yokogawa Electric Corp. & $-8,20$ & 37,37 & $2.372,00$ \\
\hline 6857 & Advantest Corp. & 3,55 & 34,53 & $2.307,00$ \\
\hline 6902 & Denso Corp. & 103,77 & 31,67 & $5.756,00$ \\
\hline 6952 & Casio Computer Co., Ltd. & 7,83 & 64,23 & $1.681,00$ \\
\hline 6954 & Fanuc Corp. & 89,66 & 60,00 & $25.985,00$ \\
\hline 6971 & Kyocera Corp. & $-302,28$ & 53,95 & $6.215,00$ \\
\hline 6976 & Taiyo Yuden Co., Ltd. & 7,53 & 15,64 & $2.012,00$ \\
\hline 7735 & Screen Holdings Co., Ltd. & $-56,61$ & 18,07 & $9.470,00$ \\
\hline 7751 & Canon Inc. & 1,11 & 68,36 & $3.134,00$ \\
\hline 7752 & Ricoh Co., Ltd. & $-10,87$ & $-8,03$ & $1.071,00$ \\
\hline 8035 & Tokyo Electron Ltd. & 23,42 & 50,27 & $19.415,00$ \\
\hline 7201 & Nissan Motor Co., Ltd. & $-0,79$ & 27,75 & $1.116,00$ \\
\hline 7202 & Isuzu Motors Ltd. & 2,79 & 24,60 & $1.680,50$ \\
\hline 7203 & Toyota Motor Corp. & 18,09 & 26,42 & $7.424,00$ \\
\hline 7205 & Hino Motors Ltd. & 74,62 & 31,29 & $1.394,00$ \\
\hline 7211 & Mitsubishi Motors Corp. & 1,84 & 23,55 & 784,00 \\
\hline 7261 & Mazda Motor Corp. & $-0,26$ & 19,14 & $1.521,50$ \\
\hline 7267 & Honda Motor Co., Ltd. & 15,79 & 16,93 & $3.767,00$ \\
\hline 7269 & Suzuki Motor Corp. & 6,47 & 15,62 & $5.638,00$ \\
\hline 7270 & Subaru Corp. & 1,55 & 50,10 & $3.607,00$ \\
\hline 7272 & Yamaha Motor Co., Ltd. & $-0,27$ & 33,66 & $2.350,00$ \\
\hline 4543 & Terumo Corp. & 48,61 & 20,66 & $5.950,00$ \\
\hline 4902 & Konica Minolta Inc. & 3,87 & 46,18 & 972,00 \\
\hline 7731 & Nikon Corp. & 9,41 & 41,15 & $1.834,00$ \\
\hline 7733 & Olympus Corp. & 0,40 & 16,79 & $4.025,00$ \\
\hline 7762 & Citizen Watch Co., Ltd. & $-0,14$ & 36,27 & 855,00 \\
\hline 9412 & Sky Perfect JSAT Holdings Inc. & $-19,71$ & 47,10 & 486,00 \\
\hline 9432 & Nippon Telegraph \& Telephone Corp. & $-4,84$ & 32,91 & $5.311,00$ \\
\hline 9433 & KDDI Corp. & $-86,75$ & 38,22 & $2.884,00$ \\
\hline 9437 & NTT DoCoMo Inc. & $-187,16$ & 49,57 & $2.835,00$ \\
\hline 9613 & NTT Data Corp. & $-30,52$ & 36,16 & $1.241,00$ \\
\hline 9984 & Softbank Group Corp. & $-1,44$ & 4,84 & $8.555,00$ \\
\hline & & & & \\
\hline & & & \\
\hline & & & \\
\hline & & & \\
\hline
\end{tabular}

\section{The Output of SPSS}

The Influence of $\mathrm{X}_{2}$ on $\mathrm{X}_{1}$

\begin{tabular}{|l|l|l|l|}
\hline \multicolumn{4}{|l|}{ Variables Entered/Removed $^{\mathbf{a}}$} \\
\hline Model & Variables Entered & Variables Removed & Method \\
\hline 1 & DPR $^{\mathrm{b}}$ &. & Enter \\
\hline $\begin{array}{l}\text { Dependent Variable: ERC } \\
\text { b. All requested variables entered. }\end{array}$ \\
\hline
\end{tabular}

\begin{tabular}{|l|l|l|l|l|}
\hline \multicolumn{5}{|l|}{ Model Summary } \\
\hline Model & R & R Square & Adjusted R Square & Std. Error of the Estimate \\
\hline 1 &, $160^{\mathrm{a}}$ &, 026 &, 008 & 59,83833 \\
\hline \multicolumn{2}{|l}{ a. Predictors: (Constant), DPR } \\
\hline
\end{tabular}




\begin{tabular}{|c|c|c|c|c|c|c|}
\hline \multicolumn{7}{|c|}{ ANOVA $^{a}$} \\
\hline \multicolumn{2}{|c|}{ Model } & Sum of Squares & df & Mean Square & $\mathrm{F}$ & Sig. \\
\hline \multirow[t]{3}{*}{1} & Regression & 5161,880 & 1 & 5161,880 & 1,442 &, $235^{\mathrm{b}}$ \\
\hline & Residual & 196934,418 & 55 & 3580,626 & & \\
\hline & Total & 202096,298 & 56 & & & \\
\hline
\end{tabular}

\begin{tabular}{|c|c|c|c|c|c|c|}
\hline \multicolumn{7}{|c|}{ Coefficients $^{\mathrm{a}}$} \\
\hline \multirow{2}{*}{\multicolumn{2}{|c|}{ Model }} & \multicolumn{2}{|c|}{ Unstandardized Coefficients } & \multirow{2}{*}{$\begin{array}{l}\text { Standardized Coefficients } \\
\text { Beta }\end{array}$} & \multirow[t]{2}{*}{$\mathrm{t}$} & \multirow[t]{2}{*}{ Sig. } \\
\hline & & $\mathrm{B}$ & Std. Error & & & \\
\hline \multirow[t]{2}{*}{1} & (Constant) & 18,064 & 16,310 & & 1,108 & ,273 \\
\hline & DPR &,- 506 & ,421 &,- 160 & $-1,201$ & 235 \\
\hline
\end{tabular}

The Influence of $X_{1}$ and $X_{2}$ Partially and Simultaneously on $Y$

\begin{tabular}{|c|c|c|c|}
\hline \multicolumn{4}{|c|}{ Variables Entered/Removed $^{\mathrm{a}}$} \\
\hline Model & Variables Entered & Variables Removed & Method \\
\hline 1 & DPR, ERC & & Enter \\
\hline \multicolumn{4}{|c|}{ a. Dependent Variable: HARGA_SAHAM } \\
\hline
\end{tabular}

\begin{tabular}{|l|l|l|l|l|}
\hline \multicolumn{4}{|l|}{ Model Summary } \\
\hline Model & R & R Square & Adjusted R Square & Std. Error of the Estimate \\
\hline 1 &, $190^{\mathrm{a}}$ &, 036 &, 001 & 4272,09636 \\
\hline Predictors: (Constant), DPR, ERC & \\
\hline
\end{tabular}

\begin{tabular}{|c|c|c|c|c|c|c|}
\hline \multicolumn{7}{|c|}{ ANOVA $^{\mathrm{a}}$} \\
\hline \multicolumn{2}{|c|}{ Model } & Sum of Squares & $\mathrm{df}$ & Mean Square & $\mathrm{F}$ & Sig. \\
\hline \multirow[t]{3}{*}{1} & Regression & 37064695,913 & 2 & 18532347,956 & 1,015 &, $369^{b}$ \\
\hline & Residual & 985543592,965 & 54 & 18250807,277 & & \\
\hline & Total & 1022608288,877 & 56 & & & \\
\hline
\end{tabular}

\begin{tabular}{|c|c|c|c|c|c|c|}
\hline \multicolumn{7}{|c|}{ Coefficients $^{\mathrm{a}}$} \\
\hline \multirow{2}{*}{\multicolumn{2}{|c|}{ Model }} & \multicolumn{2}{|c|}{ Unstandardized Coefficients } & \multirow{2}{*}{$\begin{array}{l}\text { Standardized Coefficients } \\
\text { Beta }\end{array}$} & \multirow[t]{2}{*}{$\mathbf{T}$} & \multirow[t]{2}{*}{ Sig. } \\
\hline & & B & Std. Error & & & \\
\hline \multirow[t]{3}{*}{1} & (Constant) & 3045,049 & 1177,322 & & 2,586 & 012 \\
\hline & ERC & 10,108 & 9,627 & 142 & 1,050 & 298 \\
\hline & DPR & 34,072 & 30,450 &, 151 & 1,119 & 268 \\
\hline
\end{tabular}

\section{CONCLUSION}

Based on the results and discussion on the influence of earnings response coefficient (ERC) and dividend payout ratio (DPR) on stock price in technology sector companies listed in the nikkei 225 index, the conclusions are dividend payout ratio has a negative effect on earnings response coefficient, and earnings response coefficient and dividend payout ratio partially and simultaneously have a positive effect on stock price.

\section{REFERENCES}

1. Lev, B., \& Zarowin, P. (1999). The boundaries of financial reporting and how to extend them. Journal of Accounting research, 37(2), 353385.

2. Murwaningsari, E. (2008). Pengujian Simultan: Beberapa Faktor yang Mempengaruhi Earning Response Coefficient (ERC). Simposium Nasional Akuntansi XI. Pontianak, 23-24.

3. Scott, W. R. (2012). Financial Accounting Theory. Sixth Edition. Canada: Pearson Prentice Hall.

4. Sudana, I. M. (2011). Manajemen keuangan perusahaan teori dan praktik. Jakarta: Erlangga.

5. Kallapur, S. (1994). Dividend payout ratios as determinants of earnings response coefficients: A test of the free cash flow theory. Journal of Accounting and economics, 17(3), 359-375. 
6. Wijayanti, N. R. (2008). Pengaruh Rasio Pembayaran Dividen dan Pengeluaran Modal terhadap Earnings Response Coefficients (Erc) dengan Arus Kas Bebas sebagai Variabel Pemoderasi. Jurnal Bisnis dan Ekonomi, 15(1):114.

7. En, T. K. (2002). Pengaruh Koefisien Respon Laba Akuntansi terhadap Harga Saham dalam Masa Krisis Ekonomi di Indonesia. Jurnal Ilmiah Akuntansi. 2(2):63-73.

8. Samsul, M. (2015). Pasar Modal \& Manajemen Portofolio (second ed.). Jakarta : Erlangga.

9. Pranata, A., \& Umam, A. T. (2015). Pengaruh harga bawang merah terhadap produksi bawang merah di Jawa Tengah. JEJAK: Jurnal Ekonomi dan Kebijakan, 8(1).

10. Nugraha, R. D., \& Sudaryanto, B. (2016). Analisis Pengaruh DPR, DER, ROE, dan TATO terhadap Harga Saham. Diponegoro Journal of Management. 5(4):1-12.

11. Brigham, E. F., \& Houston, J. F. (1999). Fundamentos da moderna administração financeira. Campus.

12. Niken May Wulan Ningrum. (2017). Pengaruh Dividend Payout Ratio, Return On Asset, Return On Equity, dan Net Profit Margin terhadap Harga Saham. Simki-Economic. 1 (7).

13. Kim, S. T., Jung, C. S., \& Rho, K. H. (1991). Regional economic gap in Korea. Journal of Economic Development, 16(2), 145-167.

14. Jogiyanto, H. (2016). Teori Portofolio dan Analisis Investasi. Edisi Kesepuluh. Cetakan Kedua. Yogyakarta: BPFE.

15. Prasetya, A. C., \& Gunawan, G. (2007). Analisa pengaruh earnings surprise terhadap return saham dan uji beda return dan resiko positive earnings surprise portfolio dengan negative earnings surprise portfolio (studi kasus pada 32 saham LQ45 yang terdaftar di Bursa Efek Surabaya periode 2002-2005) (Doctoral dissertation, Petra Christian University).

16. Asplund, M., Grevesse, N., Sauval, A. J., \& Scott, P. (2009). The chemical composition of the
Sun. Annual Review of Astronomy and Astrophysics, 47, 481-522.

17. Delvira, M., \& Nelvirita, N. (2013). Pengaruh Risiko Sistematik, Leverage Dan Persistensi Laba Terhadap Earnings Response Coefficient (ERC). Wahana Riset Akuntansi, 1(1):129-154.

18. Kieso, D. E., Jerry, J. W., dan Terry, D. W. (2007). Akuntansi Intermediate. Edisi Keduabelas. Jilid Kedua. Alih Bahasa: Emil Salim. Jakarta: Erlangga.

19. Hendy, M. F. (2008). Istilah Pasar Modal A-Z. Jakarta: PT Elex Media Komputindo.

20. Widoatmojo, S. (2005). Cara Sehat Investasi di Pasar Modal. Jakarta: PT. Elex Media Computindo.

21. Setiawan dan Dwi Endah Kusrini. (2010). Ekonometrika. Yogyakarta: Andi.

22. Husiano, D., \& Suratno, S. (2014). Analisis Pengaruh Beta, Leverage, Dividend Payout Ratio, dan Earnings Persistence terhadap Earnings Response Coefficient pada Indeks Kompas 100. JRAP (Jurnal Riset Akuntansi dan Perpajakan), 1(02), 121-135.

23. Yuniarta, G. A. (2013). Pengaruh Risiko Kegagalan Utang Dan Rasio Pembayaran Dividen Terhadap Kualitas Laba Akuntansi Pada Perusahaan Yang Terdaftar Di Bursa Efek Indonesia. Vokasi: Jurnal Riset Akuntansi, 2(1):117-130.

24. Paramita, R. W. D., \& Hidayanti, E. (2013). Pengaruh Earnings Response Coefficient (ERC) Terhadap Harga Saham. Jurnal WIGA, 3(1), 1220.

25. Sihombing, B. (2017). Pengaruh Dividend Payout Ratio, Return On Asset, dan Penjualan terhadap Harga Saham Perusahaan Manufaktur di Bursa Efek Indonesia. Jurnal Manajemen dan Bisnis, 11(1), 26-36.

26. Wijaya, I. G. O., \& Suarjaya, A. A. G. (2017). Pengaruh Economic Value Added (EVA), Return on Equity (ROE) dan Dividend Payout Ratio (DPR) Terhadap Harga Saham Perusahaan Manufaktur di BEI. E-Jurnal Manajemen, 6(9), 5175-5204. 